\title{
On the margins and between the lines: Ottoman women poets from the fifteenth to the twentieth centuries ${ }^{1}$
}

\author{
Didem Havlioğlu \\ Languages and Literature \& Middle Eastern Center, University of Utah \\ 255 So. Central Campus Dr. RM 1400, Salt Lake City, Utah 84112, USA \\ didem@hum.utah.edu
}

\begin{abstract}
Ottoman women poets appear in the major biographical dictionaries produced throughout Ottoman literary history; however, unlike the overwhelming majority of male poets, their presence in these documents is justified or explained as something very unusual, and the stories of woman poets have been built up, over centuries, into a discourse dominated by the male dictionary writers. The first half of this article challenges this discourse, mapping its structure and proposing that it can no longer be taken at face value. In the second part, the article proposes a new approach, structured around an alternative set of categories for studying these biographical dictionaries-dictionaries which will remain the major sources for studying women poets until their own poetry can be fully deciphered and analyzed in relationship to each other.
\end{abstract}

\section{Keywords}

Ottoman women poets, literary history, women in biographical dictionaries

In the eye of this world's people, being a Turk is an honor Would that I were garlic in their sour tarhana soup ${ }^{2}$

The marginal—and exceptional—position of women poets in the history of Ottoman literature is illustrated in the above lines composed by Mihri Hatun

${ }^{1}$ I would like to thank Prof. Walter Andrews for his invaluable contributions to the translation process for most of the poems mentioned in this article. The poems, in their original Ottoman Turkish and in English translation, will be collated and published on the Ottoman Text Archive Project (OTAP), under the title "A Poetry Collection of Ottoman Women from $15^{\text {th }}$ to $20^{\text {th }}$ Centuries" (http:courses.washington.edu/otap).

2 "Şimdiki halkun katında Türklüktür itibar / Keşlü tarhanalarında sum olaydum kaşki", Mihri Hatun, "Divan," Süleymaniye Kütüphanesi, T 3974, 155 b. 
(c. 1460-1515), the first Ottoman woman poet whose divan (poetry collection) survived entirely intact, there being four manuscript copies still in existence. Mihri is one of the most well-known women poets in major Ottoman literary histories-histories that tell of "a woman poet" who is beautiful, feminine, and virginal, and the heroine of a notorious love story. Mihri's own poetry, however, gives a completely different picture of her, and one that is in sharp contrast to these literary representations. Being far from naïve, she is very well aware of the positioning of her gender in Ottoman literary circles, and how it works against what she wants to achieve: to be a respected poet among her peers. Rather than apologizing for her gender identity, though, she embraces it; and uses its preassigned marginality in subversive ways that are to her advantage. The strong ironic tone of the above lines is a good example of her style, and communicates what it means to be a woman poet in her milieu. A brief analysis of this couplet will reveal what a woman poet thinks of her self vis-à-vis the dominant literary discourse.

In the first line, Mihri insinuates that, for "this world's people," being a Turk is all that is required in order to be honorable. By "this world's people" she means the "common" people: i.e., those who cannot appreciate the deeper meanings contained in the other-the poetic-world. ${ }^{3}$ In the late fifteenth century, when she was composing her poetry, the word "Turk" meant not only a nomad and/or villager, but also "beautiful." 4 Thus the first line means that for the common people, beauty is the sole value of poetry and implicitly suggests that those who can appreciate the "other" world-those who are the masters of this kind of poetry-will know that beauty is only the decoration on the surface, and that, as this kind of poetry allowed for layers of meaning, the true value lies beneath the surface. Having set up the contrast between the common people and the masters, in the second line she gives an example of the situation. As a way of criticizing the common people and their misjudgments, she says she wishes to be garlic in their sour tarhana soup (the beauty of the peasants). ${ }^{5}$ During my research, I have not come across any recipe which

\footnotetext{
${ }^{3}$ For a discussion of "this" and "that" world, and the mystical implications of Ottoman poetry, see Walter Andrews' Poetry's Voice, Society's Song: Ottoman Lyric Poetry (Seattle: University of Washington Press, 1985), p. 70.

${ }^{4}$ For a discussion of the meaning of "Turk" and its historical usage, see Kafadar, Cemal, "A Rome of one's own: reflections cultural geography identity in the lands of Rum", Muqarnas 24 (2007) 7-25.

5 Tarhana is a traditional soup made from dried curds and flour and it can be considered the cheap food of the common people because of its ingredients. For further information on the historical origin, nutritional facts and various ways of preparing tarhana soup see Özdemir, S.,
} 
suggests that garlic be put in this kind of soup. Thus by relating herself to garlic, we realize she represents herself as an extra flavor in the big pot of soup: sarcastically, she wishes to be garlic even though she knows that the common people could not stomach it in their soup-in other words, they cannot appreciate unconventional tastes. Clearly, the metaphor of soup stands for common or popular poetry, and Mihri represents herself as an ingredient which is out of place in it: this is a metaphor for the woman poet, who was not supposed to exist in the world of poetry.

The complexity of these lines is evidence of Mihri's quality as a poet. She does not simply put all male poets into one category; rather, she makes a clear distinction between the "common" people of "this" world, and the "masters" of "that" world, and points to her marginal situation between them. To prove her point, she leaves a hint in the second line which would hardly be caught by the common people. She makes use of a traditional poetic device, tenasüb (relationship), between the words Turk and garlic. At first glance, the connection between Turk and garlic might seem odd: however, when we recall that one of the synonyms of garlic is Türk-i rustayan, the poetic play reveals itself. The reason for her desire to be garlic is that she wants to be respected, just like being a Turk is considered honorable.

A complaint echoes within her ironic tone: although she evidently is a good poet who can manipulate the poetic rules, the common people undervalue her. Her sarcasm stems from the fact that she is much better than her critics and the oddity of garlic in tarhana soup points to her situation as a woman in the world of poetry. Even though she was one of the rare women poets who were appreciated by the intellectuals, i.e., the masters, this did not change the fact that she was marginalized. As a matter of fact, these intellectuals were precisely the ones who both included her in the elite club of poetry, but also marginalized her and women like her as constituting a separate and unique category based on their gender. Her sarcastic tone of voice signifies her criticism both of the common people who cannot appreciate her, and of the intellectuals who accept but also marginalize her.

The point Mihri makes in the above lines, regarding the marginal and exceptional position of a woman poet in Ottoman literature, can be traced through major works of Ottoman literary history, such as the tezkires (biographical dictionaries). The obvious evidence of this marginalization is that today we know of only about 35 women poets from the fifteenth to the

Göçmen, D., and Kumral Yıldırım, "A traditional Turkish fermented cereal food: tarhana”, Food Reviews International, 23/2 (2007) 107-21. 
twentieth centuries, compared to more than 400 male poets, as based on the tezkires. Among the women poets who wrote Ottoman court poetry, only 11 of them collected and published their work. Accordingly, we know of these women poets because they appear in tezkires, which comprise the major source for Ottoman women's literary history. In a field where there are only very few written documents by or about women, tezkires provide unprecedented - but also unchallenged-information about women poets. Throughout Ottoman literary history, the information related to us through the tezkires has mostly been taken as a matter of fact. In addition to the obvious marginalization of women as based on numbers, the nuanced and elaborate language used for the same purposes has not been subjected to critical investigation in a comparative manner. So what we believe about Ottoman women poets today is what the male tezkire writers wrote down, 500 years ago. Although this information has been recycled over and over again since the sixteenth century, we still do not know why there were very few women poets, or why these women poets were both accepted and marginalized by the male club. For a woman, what criteria had to be met in order to be a poet? Were they different from those for a man? Although we cannot decipher from the tezkires what women poets thought of themselves - this has to be done by diligent analysis of their own work-we can find out the story of the women poets as composed, delivered, and consumed by men. Having said that, deciphering these stories told by the tezkire writers is also a necessary step towards understanding and contextualizing women poet's writing.

This study reads the women poets' entries in the tezkires in a comparative manner, over a period of 500 years, to point out a specific discourse constructed to talk about women by the tezkire writers and how it is developed, improved, or changed over time. First, it will point to the systematic categorization of "women" and the sub-categories such as their morality or sexuality, to define the term as used in the tezkires. Then it will move on to the women poets and investigate whether, through their own poetry, they offer alternative information about being a woman poet vis-à-vis the dominant discourse about women poets in literary circles. A close comparative analysis of their poetry will suggest an alternative categorization of their existence as marginal, silent, and subcurrent.

The scope of this article is limited to what the tezkire writers included in their works. Accordingly, I will only discuss the poets of Ottoman court poetry, and mostly the women poets included among these. Last but not least, I will also mention relatively new research findings about women poets who were not included in the tezkires, findings that underscore the limitations of tezkires as major sources. The period I will cover starts with the earliest tezkires from 
the sixteenth century, and ends when women poets and writers start producing modern poetry and novels. This is a practical rather than deliberate choice, as there is no clear-cut line in the early twentieth century which separates 'classical' Ottoman poetry from 'modern' Turkish writing. ${ }^{6}$

\section{Ottoman women's literary history}

As women did not leave many primary documents, Ottoman Women's Studies is still mainly based on texts produced by men. ${ }^{7}$ This does not mean that investigating women's agency in history is impossible: on the contrary, there has been groundbreaking research about the construction of gender that is based on documents written by men. However, making use of these documents requires unrelenting attention to intertextuality and the principles of critical interpretation. Having said that, there are some basic but crucial points to consider before making any attempt to rehabilitate the history of Ottoman women. Cemal Kafadar lays out the research problems in approaching Ottoman women in a threefold manner. ${ }^{8}$ First, "Ottoman women" is a problematically broad category, which encompasses different regions, ethnic and religious backgrounds, and social classes: in adopting an approach structured around this concept, a great deal of detail is missed. Second, the tendency to look at the Ottoman past from the stance of the present often reduces and simplifies issues, whereas, in fact, over the centuries there was considerable change and complexity. Third, by defining "women" as a unitary category in contradistinction to men, one automatically puts women in a marginalized position: as a matter of fact, most of the research on Ottoman women poets

${ }^{6}$ On the contrary, modern Turkish writing as a movement should be situated within the context of Ottoman literature, and considered as an evolution from earlier periods; however, for the purposes of this study, it is appropriate to limit the scope to the period before the tezkire tradition evolves into encyclopedias and anthologies, and women writers start producing work in modern genres such as the short story or the novel.

7 The majority of Ottoman documents that form the basis of traditional scholarship are written by men and are misogynistic. The tradition of misogyny is not, however, exclusive to the Ottomans; as King and Rabil Jr. note in their introduction to Other Voices of Europe Series (King, Margaret and Albert Rabil Jr. (eds.) in Poems and Selected Letters of Veronica Franco (Other Voices of Early Modern Europe Series), Margaret Rosenthal and Ann Rosalind Jones (eds.) (Chicago: University of Chicago Press, 1998), it is inherent in both eastern and western traditions dating back to 500 BCE.

${ }^{8}$ Kafadar, Cemal "Women in Seljuk and Ottoman society up to the mid-nineteenth century", in 9000 Years of the Anatolian Women, exhibition catalog (Istanbul: Turkish Republic Ministry of Culture, General Directorate of Monuments and Museums, 1993), p. 192. 
considers women poets to be a separate category, just as the tezkire writers did, and thus upholds the tradition of marginalizing them. In addition to Kafadar's guidelines, I would like to stress an imperative step towards including women as active ingredients of the narratives of history, and that is to deconstruct the centuries-old, unified and marginalized category of "women". Without having done that it will be almost impossible to contextualize gender relationships and understand resistance of women.

Although there is a growing body of research on Ottoman women poets, there has not yet been a study which focuses on the role of their contribution to the production of culture and their contextualization in the major Ottoman literary histories. The several survey articles on Ottoman women take the first step towards this goal, introducing biographical information in a chronological manner based on the information gathered from the tezkires, but they do not situate them vis-à-vis the dominant patriarchal culture. We know that, although it was rare, it was possible for Ottoman women to speak out and/or write in male circles: indeed, some received awards for their accomplishments. ${ }^{9}$ Mübeccel Kuzıltan's survey article is the first of its kind, and makes an invaluable contribution by providing a list of Ottoman women poets and the available sources in the field. However, as Kiziltan and many of her successors take the major literary history documents at face value, they only confirm the tezkire writers' discourse regarding women poets.

Among the articles written on Ottoman women poets, only Kemal Silay's work tries to contextualize their poetic voice. ${ }^{10} \mathrm{He}$ addresses the question of the 'feminine voice' and suggests that as it is a constructed category within the dominant discourse, women poets could not create a totally female poetic tradition. He argues that "upper-class Ottoman women who wanted to become classical poets had to find other ways of acceptance, and for this they had to negotiate a clever way". ${ }^{11}$ However, this "clever way" is rather ambiguous and problematic conceptually because we do not know how it could be created within the dominant system. If it cannot, this argument puts Ottoman women's writing into a dangerous impasse situation. If some women did actually write in this "clever way" we have no means of knowing about them as they would not have been accepted in the main literary circles, so we have to

${ }_{9}$ We also know that there were Alevi and Bektaşi women poets who wrote in folk genres, which is a subject that is yet to be explored. For a discussion, see Bahadır, İbrahim, Alevi ve Sunni Tekkelerinde Kadın Dervişler (Istanbul: Su, 2005).

${ }^{10}$ Silay, Kemal, "Singing his words: Ottoman women poets and the power of patriarchy," in Zilfi, Madeline (ed.), Women in the Ottoman Empire (Leiden: Brill, 1997), pp. 197-213.

${ }^{11}$ Ibid. 
accept that there was no women's writing. To be accepted in the dominant tradition, however, women poets needed to follow the rules, but this does not mean that they did not have distinct voice. As I will discuss later in this article, being accepted in the male club allowed some women poets to raise their voices from the margins and that is the very reason why their voice is distinct.

Walter Andrews and Mehmet Kalpaklı are the first to offer a critical examination of the tezkires as the major literary histories of Ottoman women and set out the fundamental problems regarding the representation of women poets in these documents. ${ }^{12}$ They lay out the problems of depending on these texts and, through a close reading of various examples from early modern Ottoman literary history, point to the curiously sexually explicit language used to represent women poets in these documents. ${ }^{13}$ As they suggest, this language suggests that the tezkire writers did not know how to talk about poets who happened to be women: the underlying suggestion is that poetry is "men's business", in which it is not appropriate for women to engage. The main reason for this, they propose, is that poetry is about love, which has physical, social, economic, and political motivations. When women become poets, they trespass within the gender categories, entering into the male domain: for this reason, they are subject to discrimination and their morality is called into question. This study takes Andrews and Kalpakli's conclusions as a point of departure: it accepts their argument that women poets have been outcasts in the field of poetry, and investigates the curious language used to represent women throughout Ottoman literary history. By including more examples

${ }^{12}$ Andrews, Walter G. and Mehmet Kalpakli, The Age of Beloveds: Love and the Beloved in Early-Modern Ottoman and European Culture and Society (Durham: Duke University Press, 2005), pp. 197-216.

${ }^{13}$ In this article I refer to the period roughly from the end of the fifteenth century through to the seventeenth as the "early modern", rather than "medieval". The latter term connotes backwardness, whereas in fact this period in Ottoman literary history is the early stage of an "enlightenment" in terms of developments in arts and literature. It is in this period that poets such as Ahmed Paşa, Ahmed-i Dai, Necati Bey, Revani, and Tacızade Cafer Çelebi composed their poetry, laying the foundations of the Golden Age of Ottoman poetry. Furthermore, the tezkire writers such as Sehi Bey, Latifi, and Aşık Çelebi developed the first critical approaches to poetry in this period. "Early modern" also fits this study, as women poets emerge as self-conscious individuals who were aware of their gender and class in terms of how they saw themselves and how they were perceived. For other studies using the term "early modern," see Zilfi, Women in the Ottoman Empire; Goffman, Daniel, The Ottoman Empire and the Early Modern Europe (Cambridge: Cambridge University Press, 2002); Andrews and Kalpakl1, The Age of Beloveds; and Thys-Şenocak, L. Ottoman Women Builders: The Architectural Patronage of Hadice Turhan Sultan (Burlington: Ashgate, 2006). 
from later centuries in a comparative manner, I would like to add that the sixteenth century discourse regarding women poets remained fundamentally unaltered until the twentieth. If it changes at all, it is only by becoming even more elaborate: indeed, if we focus on a new set of categories that are different from the tezkire writers, it is possible to see that the earlier periods actually seem to be more open-minded towards accepting women poets than those from the seventeenth or eighteenth centuries.

\section{The tezkire tradition and its major categories for women poets}

The tezkires are massive collections, which present poets according to specific qualities such as their paternal genealogy, education, and administrative positions, along with examples of their poetry. The tezkires served the purpose of keeping a record of famous poets in Ottoman literature. In Sehi's Heşt Bihişt (Eight Heavens), the first tezkire written in Ottoman literature, he mentions in his epilogue that he finished it in 1538-39 and presented it to Sultan Süleyman $\mathrm{I},{ }^{14}$ and that he wrote it to prevent the poets from being lost to the future. ${ }^{15}$ His successors, Latifi, Aşık Çelebi, and Kınalızade Hasan Çelebi, adopted the same goal. In later periods, tezkire writers followed the same model in terms of their form; however, whereas the sixteenth-century tezkires do not acknowledge each other, but repeat the same information, from the seventeenth century on the tezkires appear as an addition $(z e y l)$ to each other. For instance, Safayi wrote his tezkire in the eighteenth century as a zeyl to Ruza's tezkire from the seventeenth; likewise, Fatin wrote his as a zeyl to Safayi's; and finally, İbnülemin wrote Son Asir Türk Şairleri as a zeyl to Fatin's in the twentieth century.

Sehi Bey and his successors not only recorded hundreds of poets; they also made conscious choices about what constituted a good poet, what characteristics poetry should possess, and, thus, who should be included or excluded in their tezkire. In addition to creating the first canon of Ottoman literature, these biographers set the rules for the long-lived traditions that, in time, developed into the poetics of Ottoman literature. They not only wrote histories of Ottoman literature, they developed a critical stance toward literary production itself, reflecting the value judgments of their time and intellectual milieu.

${ }^{14}$ Sehi Bey, Heşt Behişt, Günay Kut (ed.) (Boston: Harvard, 1978), p. 6.

15 Tolasa, Harun, Sehi, Latifi, Aşık Çelebi Tezkirelerine Göre 16. Yüzyzlda Edebiyat Araştırma ve Eleştirisi (İzmir: Ege Üniversitesi, 1983), p. 63. 
Likewise, they set the rules for becoming a woman poet and for how to talk about them.

The categorization used by Sehi Bey in his tezkire illustrates his personal choices. He creates a sub-section in which he lists two women poets under the specific title Zikrün-nisa, "Mention of Women Poets." The first curious point here is that he felt the need to explain why he included women poets.

In this age there are two women poets. Because their poems are beautiful, their couplets are matchless, their gazels are popular, and their fame considerable, they have been included in this biographical collection. ${ }^{16}$

Between the lines, his statement echoes a widely accepted belief that poetry is not women's business - or, as one of the extracts of Mihri's poetry below suggests, that women were believed to be not smart enough. For that reason he presents Zeynep and Mihri as exceptional women.

One of the major differences between Sehi and his successor Latifi is that Latifi chooses to organize his work alphabetically. In his work, woman poets are not marginalized by restriction to a specific category; however, the language and style he uses to introduce them suggests that they remain relegated to the margins. Later tezkire writers follow Latifi's model for their entries on women poets.

This language suggests that when the subject of research is a woman poet, the tezkire entry format proves problematic. For tezkire writers, a woman poet's biological gender was clearly the category of paramount importance. In their eyes she was a woman first, so any of her qualities had to be superseded by her gender. The categories used by tezkire writers-such as information about name, hometown, education, and administrative positions — set out the criteria that are constitutive of the concept of "poet" in Ottoman literary circles. If these categories had been set by and for women, they would, in all likelihood, have included the alternative ways in which women were educated; or, instead of emphasizing jobs such as kadılık or müftülük, which were the preserve of men, they would have included jobs such as midwifery or wet nursing. Looking at women from a male perspective, using male-centered categories, illuminates only a very limited part of a woman's life for it principally regards the things that they lack, that they cannot have. Since there was not much to say about women using these categories, the tezkire writers created a specific category of "women poets" based solely on gender. In identifying a specific category of "women," the tezkire writers constructed a specific discourse to talk about them. It is possible to trace the outlines of this discourse in their

${ }^{16}$ Andrews and Kalpakl, The Age of Beloveds, p. 197; and Sehi Bey, Heşt Bihişt, pp. 288-9. 
language, clarifying the categories they used to represent women poets, which do not give substantial information but mostly speculation. Apart from usual categories, there are some additional ones that are highlighted only in women's entries and are not mentioned for male poets: for example, their virginity or marital status. In later periods, virginity is no longer mentioned; it is replaced, however, by an emphasis on marital status. As it would be naïve to assume that these categories were randomly picked, it may be plausible to see them as defining what it is to be a legitimate women poet from the perspective of male critics.

\section{Education}

As tezkire writers are particular about how much a poet was educated, we can assume that education was an expected quality of a poet. However, it is necessary to clarify the kind of education that a poet had to possess: the relevant education was not something one could receive at school. Although it helped to speak Arabic and Persian, to have learnt reading and to have an understanding of the Qur'an, the intellectual capacity of a poet was more important. According to the tezkires, most of the poets studied with an acclaimed master poet for a period of time. This kind of hands-on education required studying major Arabic, Persian, and Turkish poets; practicing composing poetry by writing nazires (parallel poems) to these poets' works; being engaged in artistic environments such as meclises (literary salons); and, finally, building a reputation first as a student of a particular master, and then as a poet in his/her own right, so that $\mathrm{s} /$ he could find patrons to appreciate and support his/her poetry.

What we know about the education system of the Ottomans does not explain how women poets received their education and the tezkire writers are also not clear about this issue. This could be because they simply did not know. We already know that girls could attend sibyan mektepleri (primary schools), but it is not clear how a woman could acquire education beyond this. We could simply assume, perhaps, that they were educated at home; nevertheless, we know that there were other avenues available for women who wanted to take further educational steps. Leila Ahmed and Annemarie Schimmel, for instance, note that heterodox Islamic traditions allow women to practice religious consultation, which eventually results in intellectual growth. ${ }^{17}$ A good

17 See Ahmed, Leila, Women and Gender in Islam: Historical Roots of Modern Debate (New Haven CT and London: Yale University Press, 1992); and Schimmel, Annemarie, Mystical Dimensions of Islam (Chapel Hill: University of North Carolina Press, 1975). 
example of such a practice is Asiye Hatun's dream book. ${ }^{18}$ In this text, Asiye Hatun, a devout sixteenth-century Muslim woman, registers her dreams and her correspondence with a Halveti şeyh (Muslim religious leader). The dreams trace her process towards becoming a mature Muslim. The requirements of literary education had both negative and positive connotations for women poets. Even though most of the male poets were educated at public schools such as medreses, as explained above, this was not a requirement for becoming a poet. Working closely with an already acclaimed poet was the process that was nearly essential. In this context, although women did not have to attend higher education-which was in any case not available for them- to become a poet, they had to establish relationships with male poets as both mentors and colleagues. This seems to be another but less-obvious obstacle from our modern point of view, as we think men and women led segregated lives. If our assumption is valid, then the women poets had female mentors or female-only courts. However, women poets do not mention anything about this issue. The question is, therefore, were women and men really segregated in literary circles in the way we think or did literary circles have social codes different from other public spaces? Some women poets' entries suggest that they worked with male poets such as Mihri and Müeyyedzade Abdurrahman Çelebi (14561516), but other than that there is not enough data to answer these questions.

\section{Influential fathers and networking}

Based on the tezkires, almost all of the women poets we know of had influential fathers and an extended family. The important point here is that what we know about their personal backgrounds is all in relation to their male family members, male patrons, and male colleagues. Their relations to the women in the family or-if indeed there were any-to women patrons, are left out in earlier periods and mentioned only briefly in the later periods. This is a significant point for women poets as the women in their lives must have played important roles, but this is something of which we know nothing. We are left with the tezkire writers' representations of the women poets, which are biased and limited to their ability to access women's lives.

Besides having an influential father, building a network among one's cohort of colleagues was an effective way to become an accepted poet. Given the

${ }^{18}$ Kafadar, Cemal, Rüya Mektuplar: Asiye Hatun (Oğlak: Istanbul, 1994). 
importance of communal acceptance, these fellow poets were the people who could actually approve or disapprove of a poet. For instance, as already discussed, it was common practice to support other poets by being their patrons or mentoring them in their early careers. For instance prominent poets such as Müeyyedzade supported many younger poets, including both Necati (14511509) and Mihri. Necati also became the protector of poets: among the poets he mentored was the first tezkire writer, Sehi Bey. Moreover, establishing professional relationships in the poetic sphere-such as by writing nazires or networking in court gatherings - was necessary for a poet's career. The reason is quite simple: poetry was a social art, and it was composed and consumed in social settings, such as a meclis, a garden party, or a private gathering. To build a good reputation meant being known among certain people. This requirement applied to both men and women. As mentioned earlier, we do not have enough information on the extent to which women were part of these circles.

The quality of the works of women poets is acknowledged in the tezkires, and their collegiate relationship with male poets is mentioned, though with caution-in other words, it is explained and excused with an emphasis on the necessity of such a relationship. A poet's relationships to other members of this distinct community played an important role in his reception, since he had to prove himself to the major actors within it, and excelling in poetry could be a way to legitimize his position and post. This factor helps explain the small number of women poets in this community, due to their supposed inability to participate in male circles, or the impossibility of a woman holding a significant administrative position. The women poets whom we know of today are the select few among the women poets of the time who, albeit from the margins, participated in this network of male relations.

\section{Moral and marital status}

Poetry meant having relationships with men, either virtually in the poetic world or actually in the literary world; and, for the tezkire writers, this creates suspicion about women poets' honor. Most probably because of this issue, this category is the most elaborate in the tezkires. Early tezkire writers seem to bring up the issue of 'virginity' in support of women poets, by way of showing them to be honorable women while still legitimate poets. They also bring up the incongruity between marriage and poetry. Likewise, in later periods divorce among women poets seems to have been more popular. I will discuss the case of Mihri's virginity; Zeynep's marriage as compared to Mihri's single 
status; Moralizade Leyla's divorce and the suspicion of her lesbianism: these are all examples in the tezkires of a discourse that paid close attention to the morality, sexuality, and marital status of women poets.

The tezkire writers dwell at length on Mihri's beauty and chastity. Among them, Aşık, as well as following the style of his predecessors, explains that her poetry was as beautiful as herself. The following passage is extracted in full as translated by Andrews and Kalpaklı, because it is a significant quote from Aşık highly relevant to the issues discussed here:

She made the adornment of the virgins of meaning her own with the dowry [mehr] of verse and brought them to her bridal chamber of [carnal] pleasure. In the lovely poems [where] she describes beautiful beloveds there is the virginal quality of Joseph. While the male poets had a craving for virgins of meaning, being a woman [herself] [they] came cheap. Although in her poetry there are some indecent words, they are like the menstrual fluid of men and some find deficient expressions, but those, being of the class, which needs guidance, are affected by this influence. On the whole she is not ignoble, her poetry is middling good, her writing is like a woman's embroidery, and her prose is wanton. [According to the saying] "The male lion is a lion [i.e., it has the attributes of a lion-strength, bravery, ferociousness, etc.] but is the lioness not a lion too [does she not have the same attributes]?," she was not entirely free of boy-chasing. ${ }^{19}$

Aşık introduces Mihri as a modest, virgin, and pious woman on one hand; and as a wanton (rospuyane) woman who is a lover of actual men or boys on the other. This contradiction reflects Aşık's ideas and ideals of the poetic world and how it can be different from the real world, a contradiction that he does not try to challenge. Instead, he attempts to pursuade with elaborate explanations. Thus, Mihri is both a virtuous and a coquetish woman, just as she is a respected woman but also a poet. First he introduces her real world identity: a never-married woman coming from a respected family. However, the description of her "girlhood" as having a "maiden quality of Joseph" is rather peculiar. In the literary world, or in the Qur'anic tale and subsequent legends, Joseph was the paragon of both male beauty and chastity. Also, he is one of the classic beloveds who appear in most of the poetry of men. In other words, men

\footnotetext{
19 Arayis-i ebkar-1 me’anisi mehr-i nazm ile kendinün idinüp hacele-i tasarrufuna götürmüştür. Güzeller vasfinda olan hub şiirlerde Yusuf kızlıgı vaki olub bikr-i ma’analara rical-i şu'era aş yirirken ol avratlıgla ucuz düşürmüşdür. Egerce eş’arında na-mahrem sözler bulunur lakin ol hayz-1 rical kabilindendir, nakıs edalar görürler ol eserden mü'essir-i istidlal kısmındandır. Ve bil'cümle alçak degül şiiri meyanedir ve yazısı kız nakşı ve inşası rospuyanedir. Erkek arslan arslan dişi arslan arslan degilmü diyu şahidbazlıkdan hali degil imiş (MeredithOwens, G.M. (ed.), Meşäirü̧ş-Şuara or Tezkere of Aşık Çelebi (London: Luzac, 1971), f. 127b); translation in Andrews and Kalpakl1, The Age of Beloveds, pp. 203 and 205.
} 
pursue Joseph in poetry as he represents ultimate beauty that cannot be captured. By comparing Mihri to Joseph, Aşık misplaces her and assigns her the role of the beloved, even though she plays the role of the lover by being a poet. This is a deliberate choice to convey Aşık's implicit argument that she is a virtuous woman in a male field-in other words, she is in out of place. In contrast to Aşılk's dilemma, Mihri is very clear about her position in the world of poetry and for that reason she calls herself Züleyha and pursues Joseph in her poetry like any other poet. The main issue here is not the gender of the beloved-it can be a man or a woman-but the gender of the poet who is active, all-controlling as a speaker, and pursuing an always-silent beloved, and is for that reason powerful but in disgiuse of the humility of love. All of these qualities are prescribed to the lover/poet who is almost always a man. When Mihri takes on this role, she breaks the gender construction of this poetic system. ${ }^{20}$ In this frame, Aşık's choice towards comparing her to Joseph and creating an androgynous space in the poetic world is not a coincidence. It is well suited to explaining the existence of a woman poet.

When Aşık explains that Mihri used "indecent words" in her poetrywhich are attributed to men with the notion of male "menstrual fluid"-he brings the feminine quality of a male poet into the picture. He continues his rhetoric about the complex gender attributes in the context of poetry when he makes a smooth connection between the phrase bikr-i mana (virgin of meaning) and the virginity of Mihri herself. The concept of bikr-i mana is at the core of poetic language as a poet's job is to create novel imagery. It is interesting that it is compared to virginity, which is a quality expected from women. Figuratively, a male poet looks for bikr-i mana in his poetry, just like a man looks for a virgin girl to marry. It is a claim of masculinity that refers to ownership and honor. Aşı1k praises Mihri's talent in creating new meanings, and compares her to male poets who crave such talent. The phrase he uses for "craving" is aş irmek, which is specifically used in reference to pregnant woman who crave strange things. Again, he gives female quality to some male poets. He seems to make two major statements: first, a good poet should have masculine qualities as a lover; and second, a masterful woman poet can have masculine qualities and this is accepted because some mediocre male poets cannot rise to the expectations of poetry so they are feminine. In a way, he

${ }^{20}$ For a full discussion of the gender-role reversal in Mihri's poetry see Havlioğlu, Didem, “Osmanlı Şiirinde Kadının Sesi: Mihri Hatun'un Hatime-yi Risalesi ve Necati’ye bir Naziresi”, in In Memoriam Şinasi Tekin I: Journal of Turkish Studies 31, Yücel Dağlı, Yorgos Dedes, and Selim Kuru (eds.) (Boston, Harvard University Press, 2007). 
defines femininity and masculinity in poetic terms, thus allowing men and women to take unexpected gender roles.

The juxtaposition between the real and the poetic world is apparent as Aşı $\mathrm{k}$ suggests that, although she was in the business of writing love poetry, Mihri never became physically involved with a man, which in this time would have implied marriage. The distinction between poetry and marriage suggests the reason for Mihri's avoidance of marriage, a critical choice in her career as a poet, as opposed to another woman poet, Zeynep. According to Aşık, Zeynep's father was a kadl, or a magistrate, in Amasya. ${ }^{21}$ Due to his support for her education, Zeynep (?-1473/4) learned Arabic and Persian languages and literature; she was also talented in music. ${ }^{22}$ At some point, she married İshak Fehmi Efendi and, for that reason, gave up poetry-perhaps before Mihri had entered the literary circles of Amasya. Most of the tezkires contrast Zeynep's choice to marry with Mihri's choice to stay single (or, as they term it, to remain a "virgin") all her life. From the mid fifteenth to the late sixteenth century, the very few women poets we know of - such as the Ottoman Zeynep Hatun, the Mughal Zeb'un-Nisa, and the Mamluk Ayisha al-Ba'unniya-also chose to remain single while they were active poets. All tezkire writers agree that Zeynep stopped writing poetry once she married:

Mihri shied away from marriage and spent her life unmarried until she died. [However] Zeynep married, lived under her husband's command and she quit poetry, and did not contact with men. ${ }^{23}$

The last phrase implies that while unmarried women had contact with men, once in wedlock they abstained both from gatherings of men and from exchanging poetry with them. The suggested conflict between marriage and poetry for women raises questions about the social role of a woman in early modern Ottoman times. Why would a woman have to make a choice between marriage and poetry? In addition to the social obligations a marriage would entail, a wife represented her husband's honor. These restrictions did not allow a woman to write poetry, an activity which suggests a virtual relationship with a man in poetic space and requires an interaction with men in literary salons.

In later periods, divorce or widowhood seem to have been alternatives to being single, even though there were women poets whose husbands supported

\footnotetext{
${ }^{21}$ Meredith-Owens, Meşairüş-Şüara, f. 83b.

${ }^{22}$ Kızıltan, Mübeccel, "Divan Edebiyatı Özelliklerine Uyarak Șiir Yazan Kadın Şairler", Sombahar, 21/22 (1994), p. 110.

23 "Mihri izdivaçdan ar idüp ölünce tecerrüd ile geçinmiş, Zeynep ere varıp eri hükminde olup şiirden ve rical ile münasebetten çekinmiş” (Meredith-Owens, Meşairü̧s-Şu'ara, f. 83b).
} 
their poetic practice from the eighteenth century onwards. I will discuss two major women poets, Fitnat Zübeyde (1720-80) and Moralizade Leyla (?-1847), both of whose poetry survived and was collected into divans. Fitnat Zübeyde came from a privileged and artistic family which contained many poets. She received an extended education and composed poetry early in her life. Her divan exists in 31 manuscript copies - the largest number among women poets. According to Mehmed Zihni, she married Mehmed Esad Efendi, someone who had no taste in poetry, and was so jealous that he asked her to cut her eyelashes: consequently, she divorced him and continued to practice poetry.

Similarly, Moralızade Leyla came from an educated and privileged family; she married for a very short period of time, and divorced due to her husband's rudeness. According to İbnülemin, Fatma Aliye tells the story of Moralızade Leyla's divorce:

At the wedding night, while Leyla was in her bridal veil, tinsel and gown, the husband apparently decided to get his new wife used to serve him from the very first night, said: "Wife, come and change this" extending his arm wrapped in chickpea plaster. Leyla rushed outside and said to the people around that she would never enter that room again. Her relatives and friends fluttered and tried to persuade her but alas, they could not send the poor girl back to the nuptial chamber. Leyla said, "I cannot stand to see the face of that man who made me hate chickpea stew all my life." Would not bestowing a girl like Leyla on a man like him mean to disregard her value and will? They made the helpless Leyla say these lines:

Drink in the rose garden, no matter what they say.

Enjoy yourself in this world, no matter what they say.

What's the difference between slur and praise to me in this world.

Let the beloveds live long no matter what they say.

All of that speaking ill of and accusing her, were not to hush her, instead they wanted her to speak. On one hand, they did not want women to read and write but on the other, they wanted, using all of their intelligence and learning, Leyla to speak up. ${ }^{24}$

We do not know the extent to which this story about Moralızade Leyla's divorce is true, but all the tezkires agree on the fact that she was divorced and

24 "Düğün gecesi Leyla, gelin elbisesiyle telli duvağı ile bulunurken zevc efendi, ilk gecesinden zevcesini hizmetine alışırmak ve kendini saydırmak fikrine itikaden mi olacak ne olacak, 'Hanım, gel şunu değiştir' diye nohut yakısı bulunan kolunu geline uzatmış. Leyla dışarı fırlamış ve artık içeriye gitmeyeceğini etrafındakilere söylemiş. Akriba ve taallukatı telaşa düşüp kendisini kandırmağa uğraşmışlarsa da mümkin değil kızcağızı hücre-yi zifafa gönderememişler. Leyla, 'Ömrüm oldukça beni nohutlu yahni yemekten iğrendiren bir herifin yüzünü görmeğe 
never married again. Though İbnülemin himself is suspicious about the story, he confirms that a man who asks his new wife to clean his wound deserves to be divorced. ${ }^{25}$

Moralızade Leyla spent most of her life writing poetry and holding meclises in her house. Although she wrote some poetry influenced by her Mevlevi religious path, most of the tezkires claim that she did not refrain from writing about love. However, Moralızade Leyla's free spirit-that is to say, her keeping the divorcee status and writing provocative poetry-caused some suspicion; thus, Mehmed Zihni claims: "She was used to women and she was from the group of lesbians" ${ }^{26}$

Other than Mehmed Zihni, none of the tezkires mention Moralızade Leyla's sexual choice. My translation of this sentence is based on the convincing explanation by Mehmet Arslan regarding the meanings of alüfte and tabakzenan. ${ }^{27}$ According to Arslan, alüfte means both "accustomed, used to," and "prostitute, immoral woman." The second part of the sentence confirms the interpretation of the first, as tabak-zenan means "lesbians." It is entirely probable that Moralızade Leyla's independent behavior caused suspicion and gossip in addition to her significance as the first woman poet who acknowledged and supported other women poets. She paid homage to her predecessors, Fitnat Zübeyde and Nesiba Hanım, by acknowledging them in her poetry; and she wrote poetry praising imperial women such as Esma Sultan. Regarding Mehmed Zihni's accusation, it is relevant to keep in mind that Moralızade Leyla was an unprecedented persona in literary history in acknowledging her fellow women. By staying a virgin, Mihri as a woman of early modern times

mümkin değil tahammül edemem.' demiş. Leyla gibi bir kızı öyle bir erkeğe vermek, Leyla’nın asla kadrini nazar-1 itibar ve itinaya almamak demek olmaz mı? En sonunda biçare Leylayı,

$$
\begin{aligned}
& \text { İç bade-yi gülşende ne derlerse desinler } \\
& \text { Alemde sen eglen de ne derlerse desinler } \\
& \text { Alemde nedir farkı bana medh ile zemmin } \\
& \text { Sağ olsun ahibba da ne derlerse desinler }
\end{aligned}
$$

Demeğe kadar vardırmışlardır. O kadar zemler, hücumlar Leyla’yı susdurmak için de değil anı söyletmek de istiyorlardı. Bir yandan kadınların okuyup yazdıklarını dahi istemedikleri halde bir yandan da Leyla’yı söyletmek içün olanca zekalarını irfanlarını sarfediyorlardı". (İnal, İbnülemin Mahmud Kemal, Son Asır Türk Şairleri (Istanbul: Türk Tarih Encümeni, 1930-42), pp. 874-9.)

25 Ibid.

26 "Kendisi alüfte-i zenan ve ser-deste-yi güruh-1 tabak-zenan imiş" (Mehmed Zihni, Meşaihirün-Nisa (Istanbul, 1878), p. 195).

${ }^{27}$ Arslan, Mehmed, Leyla Hanım Divanı (Istanbul: Kitabevi, 2003), p. 33. 
could avoid the social obligations of being a wife and under a man's control. Moralizade Leyla, on the other hand, was not only a divorcee-i.e., could no longer be represented as virgin - but also lived at a time when, according to the tezkires, women were under more social pressure. I will consider this point later, in my discussion of the women's "period of silence."

The emphasis on the moral and marital status of women poets in the tezkires points to the discrepancy between poetry and women's morality. All tezkires indicate that the state of being married is inconsistent with that of being a woman poet. Earlier ones legitimized the choice to be a poet through virginity; while later tezkires confirm this dilemma by underscoring the increasing divorce rate among women poets. What is more, after divorce, the moral status of these women could not be restored. What we understand from the tezkires is that poetry and the discourse of love are a man's business, and that respectable women should not enter this field or express themselves in its language.

Women poets are outsiders by virtue of their gender, and for this reason tezkire writers felt the need to explain themselves for including them. In so doing, they not only strengthen the male discourse, but also generated entertainment with controversial stories about the women's morality. Consequently, the information given in the tezkires about women poets serves a different purpose than provision of objective information. Given the tezkire writers' inability to enter into the women's world, the categories they use to deliver the information about women poets are problematic and indicate only the male perspective: for this reason, they cannot be taken at face value.

If different categories are used-based on what Ottoman women poets had to say in their own poetry and the way they were kept out of major historiesa different picture emerges. Women poets are consistent about the message delivered in their poetry: namely, the marginal, silent, and subcurrent nature of their existence. Although each of these categories emerges most clearly in different periods, there is no doubt that they, as a whole, characterize the experience of woman poets from any of the periods of Ottoman literary history under discussion. I will discuss each of these categories in chronological order, citing examples of the works of women poets from that period. Altogether, they generate a distinct alternative to the dominant discourse of Ottoman literary history.

\section{"The marginal": the fifteenth and sixteenth centuries}

As discussed earlier, women poets were accepted but also marginalized in the tezkires. The role of outsider - considered to be rooted in natural and essential 
facts about female biology—had been cast for women poets throughout the Ottoman literary tradition. Interestingly, however, diligent attention to the clues left by the women poets reveals that they used this positioning in powerfully subversive ways. From their position on the margins, they disrupted the male-oriented system not only by their very presence, but also by signaling their awareness of this assigned positioning in the delivery of their poetic messages. The Ottoman women poets' embracing of marginality shows the power of the marginal position, and demonstrates its potential to challenge the dominant system.

Among the women poets, the most successful ones-that is to say, the ones most celebrated by their male colleagues: Mihri Hatun, Ayşe Hubba (?-1589/90), Moralızade Leyla, and Fitnat Zübeyde_-are also the ones who wrote the most provocative poetry. Interestingly, some recent studies in Ottoman literature have described their poetry as "manly," precisely because of their mastery of the form. ${ }^{28}$ This description, however, is problematic: no justification for the equation of "goodness" and "manliness" is given, and if the suggestion is just that good poetry is "manly" poetry, the argument is unconvincing to say the least. On the contrary, as I will try to show, these poets are advocates of gender equality: they demonstrate the invalidity of prevalent misconceptions about women. I will give two examples, from Mihri Hatun and Ayşe Hubba, who challenged the concept of man's intellectual superiority.

The following famous lines are drawn from the entries regarding Mihri Hatun in major tezkires, and have been referred to by literary scholars for many years:

Since they say women lack reason

All their words should be excused.

An efficient woman is much better than

A thousand inefficient men. ${ }^{29}$

These lines are justly famous: they point to her disagreements with her era's stereotypical assumptions about women. She challenges the assumption that women lack reason, stating that it is not a person's gender but their "efficiency" that determines their potential. As a woman in a male field, Mihri tried to incorporate a woman's point of view by making such arguments about equality

${ }^{28}$ See, for example, Arslan, Leyla Hanım; Kızıltan, "Kadın Şairler"; and Toska, Zehra, "Divan Şiirinde Kadın Şairlerin Sesi”, Türk Edebiyatı Tarihi (Ankara: Kültür ve Turizm Bakanlığı Yayınları, 2006), vol. 2, pp. 663-74.

29 "Çünkü nakıs akl olur dirler nisa / Her sözin mazur tutmatır reva / Bir müennes yeg durur kim ehl ola / Bin müzekkerden ki ol na-ehl ola” (Mihri, “Divan,” f. 103a). 
between genders. This was a novel position for a poet in her time: no male poet, we should note, felt the need to write about gender inequality, or to advocate for women's abilities.

Another similar example comes from Ayşe Hubba (?-1589/90):

Being feminine is no shame to the name of the sun

Being masculine is no glory to the crescent moon. ${ }^{30}$

This couplet, even though it makes use of a rather common aphorism in Islamicate literatures, echoes Mihri's lines in the context of women poets. Ayşe's claim of equality between the genders is based on the difference between the sun and the moon, both of which are valuable despite their different roles; and she alludes to the gender of the words in Arabic - in which language the sun is feminine, the moon masculine. In her poem, neither the sun nor the moon is the lesser.

Both Mihri and Ayşe are referred to as "good poets" in tezkires. As mentioned earlier, Mihri was the first woman poet whose poetry was collected into a divan. Based on the gift registry of Bayezid II, her poetry was presented to Beyazid and monetary awards were bestowed upon her on five different occasions. ${ }^{31}$ These awards show that she must have been a recognized poet during her lifetime. Ayşe Hubba Hatun, also called Ayşe Hubbi Hatun, was very well educated: she learned Arabic, studied poetry and, according to the tezkire writers, she composed mesnevis (narrative poems), kasides (eulogies), and gazels (lyric poems). Kizıltan notes that her style was not "feminine", and that she wrote just like her male colleagues. ${ }^{32}$ She was praised in tezkires for her poetic skills. According to Aşı Çelebi she wrote a mesnevi (narrative poem) titled "Cemşid ü Hurşid", but it did not survive. ${ }^{33}$ Significantly, Müjgan Cunbur has argued that the mahlas (poetic persona) "Hubbi", with which Ayşe Hubba signed her gazels in the last hemistich, can also be found at the end of a risale (message or letter), a short work on religious warfare entitled "İmadu'l-Cihad". ${ }^{34}$ This is an interesting discovery, as this narrative poem was written following a tradition of praising gazas (military expeditions in the name of Islam) and gazis (soldiers who fought in the name of Islam), and the

\footnotetext{
${ }^{30}$ Andrews and Kalpakl1, The Age of Beloveds, p. 209.

${ }^{31}$ Erünsal, İsmail E., "II. Bāyezid Devrine Ait Bir İn 'amat Defteri”, Tarih Enstitüsü Dergisi, 10-11 (1981), p. 303.

32 Kızıltan, "Kadın Şairler”, p. 114.

${ }^{33}$ Meredith-Owens, Meşairüss-Şuara, f. 186b.

${ }^{34}$ Cunbur, Müjgân, “İmadu'l-cihad ve XVI Yüzyıl Kadın Şairlerinden Ayşe Hubbî Kadın”, in Türk Tarih Kongresi Bildirileri (1988), p. 901.
} 
whole poem was composed with references to sures (Qur'anic verses) and hadis (records of a saying or action of the Prophet Muhammad) about the prophet. If Ayşe Hubba Hatun wrote this poem, as Cunbur claims, it shows that she had significant education in theology, and an interest in religious warfare.

The cases of Mihri and Ayşe confirm the previous arguments that women poets' marginalization was based only on their gender, not on their literary skills. However, here I have tried to show that what makes them distinct from male poets is their awareness of their gender, and the manner in which they use this awareness to their advantage- that is to say, in how they inflect their messages to the dominant male discourse. Were they not part of this dominant discourse-that is, had they been entirely excluded-they would not have their voices heard at all: they would be lost to history, as was the case for the women poets whom I describe here as the "silent group".

\section{“The silent": the seventeenth century}

It would be impossible to talk about women's silence, beyond speculation about it, if we had no evidence. However, thanks to relatively recent discoveries about the women poets that we know of today, we also know that there were many women poets who were not accepted or included in the major histories. Over and above the fact that women poets are very few in number throughout Ottoman literary history, the seventeenth century exhibits a curious gap, during which there is not a single woman poet mentioned in the tezkires. This appears to be a period of amnesia regarding women poets-since it is hardly possible that they actually disappeared. This does not mean that, besides the ones treated in the early tezkires, women poets did not exist up until the eighteenth century, but it may suggest that, over time, Ottoman poetry became more institutionalized, and conservative, with well-defined restrictions which made it difficult for marginalized groups, such as women, to enter. Hatice Aynur explains the clear distinction between classical and folk poetry from the seveenth century onwards, and gives examples from the tezkires about the competition between the two. There were clear-cut boundaries not only between classical and folk poets, but also between genres and forms. ${ }^{35}$ In other words, Ottoman classical poetry had become more of an elitist club, in contrast to popular literature.

\footnotetext{
35 Aynur, Hatice, "Ottoman literature", in The Cambridge History of Turkey vol. 3 The Later Ottoman Empire, Suraiya Faroqhi (ed.) (Cambridge: Cambridge University Press, 2006), p. 500.
} 
It is also worth noting that from the seventeenth century on, a period of anarchy and insurgencies sets in, as the empire goes through a decentralization process and faces the consequences of military and fiscal problems. Throughout Anatolia, the Celali rebellions set a prevailing mood of chaos which would have had a considerable impact on arts and literature. Considering the core role of the urban party setting and generous patrons within Ottoman poetic production, a change in practice during a period of social and economic unrest is not surprising. Folk literature, however, flourished, with the emergence of major masters such as Karacaoğlan, and some classical poets turning to produce folk poetry under different mablas.

Women's silence is not restricted to one period in history, however. Besides the clear gap in the seventeenth century, the relatively recent findings regarding women poets from different periods who do not appear in tezkires are suggestive of missing women poets throughout literary history. Mehmet Çavuşoğlu's coincidental discovery of a sixteenth-century woman poet, Nisayi, in a mecmua (anthology) suggests that there were probably more women poets writing during this period, but that few made it into the pages of history. ${ }^{36}$ Çavuşoğlu suggests that Nisayi’s elegy for Şehzade Mustafa, who was executed by his father Süleyman I (1494-1566), was written in a very critical tone, and this may explain her exclusion from tezkires. The following couplet gives a hint:

You allowed the words of a Russian witch into your ears

Deluded by tricks and deceit, you did the bidding of that spiteful hag

You slaughtered that swaying cypress, fruit of life's orchard

What has the compassionless Monarch of the World done to Sultan Mustafa? ${ }^{37,38}$

In this couplet Nisayi refers to the wife of Sultan Süleyman I, Hürrem Sultan $(?-1558)^{39}$ by her ethnicity, and accuses the sultan and/or Rüstem Paşa (1500?-61), his grand vezir, of complicity in her conspiracy against Süleyman's eldest son, Şehzade Mustafa. She was trying to get rid of Mustafa, a popular

${ }^{36}$ Çavuşoğlu, Mehmed, "16. Yüzyılda Yaşamış Bir Kadın Şair Nisayi”, Tarih Enstitüsü Dergisi, 9 (1978), p. 405.

37 "Bir Urus cadusinun sözin kulaguna koyup / Mekr ü ale aldanuban ol acuzeye uyup / Bag-1 ömrün hasılı ol serv-i azada kıyup / Biterahhum şah-1 alem nitdi Sultan Mustafa" (Çavuşoğlu, Mehmed, "Şehzade Mustafa Mersiyeleri”, Tarih Enstitüsü Dergisi (1982) p. 652).

${ }^{38}$ For the full text, see Andrews and Kalpakl1, The Age of Beloveds, p. 248.

${ }^{39}$ Hürrem was the most cherished concubine/wife of Süleyman I and the mother of Selim II. According to Peirce she was originally from Ukraine and her name before entering the Ottoman harem was Aleksandra Lisowska. See Peirce, Leslie, The Imperial Harem: Women and Sovereignty in the Ottoman Empire (New York: Oxford University Press, 1993), p. 58. 
and eligible crown prince, because she wanted her son Selim to become the next sultan. Süleyman had Mustafa killed in 1553. Apparently, Mustafa was an important patron of arts and poetry in his court in Amasya. Nisayi was probably one of many poets at his court, and at that of his mother Gülbahar Hatun, an earlier favorite of Süleyman. In short, Nisayi was not on the side of the winners in history. For Çavuşoğlu, this is sufficient to explain her disappearance from the pages of major historical texts; however, he adds that Nisayi's poetry has some flaws and for that reason she might not have been considered equal to the other major women poets of the fifteenth and sixteenth centuries, Zeynep, Mihri, and Ayşe. ${ }^{40}$

It is interesting that Nisayi, Zeynep, Mihri, and Ayşe, should all have been from Amasya, since Şehzade Mustafa was the last prince governor to be based there. ${ }^{41}$ In later periods, specifically in the nineteenth century, almost all women poets were from Istanbul. This is a curious detail, which raises questions about the significance of urban centers for the advance of women poets, and stands in need of further investigation.

Besides Nisayi, there is another woman poet from a later period, named Tevhide Hanım (?-1847), who did not find a place in the tezkires. She was from the small city of Manisa, and belonged to the Mevlevi path. ${ }^{42}$ Her divan was published by her foster daughter, Atiye Hanım, after she died. She brought up Atiye as a poet and musician who could sing songs and play the $u d$ (lute). The reasons for her rejection in the tezkires are likely to be, first, that she was not from Istanbul, the center of the arts; and, second, that her poetry was not in the style that was standard for the canon of her time. However, when we look at her poetry, we once more discover messages about women's issues. The following stanza is extracted from a poem written in the voice of a man who was married to two women:

About the man who were married with two wives

For some reason, I married and received the inheritance

So I married again and for that I was burnt in flames

I thought men who have two wives were comfortable

By my own hand, I myself brought a curse upon my head

${ }^{40}$ Çavuşoğlu, "Niyasi”, p. 408.

${ }^{41}$ For further information on Amasya as a center for princely courts, see Kappert, Petra, Die osmanischen Prinzen und ibre Residenz Amasya im 15. und 16. Jahrhundert (Leiden: Nederlands Historisch-Archaeologisch Instituut te Istanbul, 1976).

${ }^{42}$ The biographical information is based on Nazmi Bayçın's article, "Yurt Tetkikleri: Manisa'da Bir Kadın Şair: Bayan Tevhide ve Eserleri”, Gediz, 3 (1940), p. 35. 
There is no surprise that I suffered at the hands of those two, oh how I suffered Where ever I might turn, their quarrelling baffled me. ${ }^{43}$

Tevhide's poetry might not have made it into the canons of classical Ottoman literary history, which was defined by male critics; however, it clearly addresses important issues - here, women's criticisms of polygamy - that are passed over by male poets. The male character in the poem marries twice and for that reason, he tells us, suffers greatly. It is interesting that Tevhide choses to narrate in his voice, making him complain about the two women. The fuss regarding the two women, however, is clearly a consequence of his own poor choice to marry twice, as, in the end, she makes him turn to another woman for her advice about how to solve his problems - this woman is Tevhide herself, appearing as a character in her own poem. Her sarcastic and humorous tone ridicules him and puts herself, as a woman, in a superior position. She delivers the ultimate message: it is the institution of polygamy itself that gives a man trouble and lands him in such embarrassing situations.

Tevhide's poem echoes Mihri and Ayşe's claims of gender equality; the sarcastic tone, too, is similar to Mihri's. However, we do not have evidence that Tevhide read her predecessors. In later periods, particularly from the nineteenth century onwards, another quality is added to the characteristics of women's writing. It is possible to trace a group ethos building between the women poets, which I define as the 'subcurrent', as they generate a specific group among themselves within the dominant literature.

\section{“The subcurrent": the eighteenth and nineteeth centuries}

Ottoman women poets, although marginalized and kept silent, had realized and embraced their distinct category of "women poets". This does not mean that they accepted the negative attributions made to their gender, nor did they try to deny their identity by adopting male pseudonyms, which has been a traditional route for women to enter the world of male literature. ${ }^{44}$ At some point in their literary history, roughly the mid nineteenth century, we begin to

43 “İki evli adamın hakkında / Nereden oldu avradım da ben mirası aldım / Varıp bir dahi evlendim amma ateşlere yandım / İki evli adamların evde rahatı var sandım / Kendi destimle belayı başıma ben kendim aldım / Ne aceb yandım ikisinin elinden ah ben yandım / Nerelere gideyim kavgalarından şaşdım kaldım” (Tevhide Hanım, "Divan”, Süleymaniye Kütüphanesi, T 5724, f. 124b).

${ }^{44}$ For instance, the British writer George Elliot, or-a rare case in the history of Turkish women's writing-Cahit Uçuk. 
perceive a pattern of establishing themselves within the dominant poetic discourse by forming a kinship among themselves. As we see in Tevhide's life story, raising her foster daughter as a poet points to the fact that group consciousness among the women poets was growing by the nineteenth century. Like Tevhide, Şeref Hanım (1808-57), having no children herself, raised her niece Nakiye (1845-99) as a woman of letters. It is mentioned in tezkires that Nakiye had a divan, but apparently it has not survived. Nevertheless, Nakiye was a prominent figure in women's magazines such as Kadınlara Mahsus Gazete (The Magazine for Women). ${ }^{45}$ Likewise, Leyla Saz (1850-1936) tells the story of her visit to Adile Sultan (1826-98) when she was invited to her palace with her sister in order to keep company with Adile's daughter, Hayriye Sultan. ${ }^{46}$ Although Adile Sultan does not appear to have been a patron of women poets, nor does she mention them in her own poetry, it could not have been an arbitrary choice to invite Leyla Saz and her sister, two well-educated girls of the time outside the imperial family, to be friends with her daughter.

The importance of the growing literary culture among women poets can be underscored by an examination of the poetry they wrote in honor of each other. These women poets use a traditional practice in Ottoman poetry, writing nazires or tahmises (a poem composed by adding three lines rhyming with the first line of each couplet of a gazel) to acknowledge each other. The value of writing nazires or tahmises is the ability to create new meanings with old words. Parallelism between two poems written by two or more different poets was realized by adherence to certain rules: the parallel poem had to follow the same meter, rhyme scheme, and refrain words; furthermore, it might follow the same imagery and themes. Within the very limited space left for invention, poets managed to recycle poetry and create something new. As mentioned earlier, the long-lived tradition of writing nazires to existing ones was a feat all poets had to perform: it was a recognition and appreciation of the past, and a display of mastery. ${ }^{47} \mathrm{On}$ the surface, the women poets seem to be imitating the dominant discourse through their use of a traditional form but, seen in context, their poetry shows their distinct intentions. Besides the fact that to be able to exist in this tradition they had to follow its rules, their poetry also

${ }^{4}$ Ahmet Muhtar Begzade, Şair Hanımlarımız (Istanbul: Matbaa-i Safa ve Enver, 1895), pp. 62-3.

${ }^{46}$ Leyla Saz, Hanım, Haremin $\dot{I}_{c ̧}$ Yüzü (Istanbul: Milliyet Yayınları, 1974), p. 210.

${ }^{47}$ For further information on the nazire tradition see Ambros, Edith, "Nazire, the will-o'-thewisp of Ottoman Divan Poetry", Wiener Zeitschrift für die Kunde Des Morgenlandes, 79 (1989), 57-83: and Kalpaklı, Mehmet, "Osmanlı Şiir Akademisi: Nazire", Türk Edebiyatı Tarihi, 2, pp. 133-7. 
served as a space for registering their existence. Thus, they used the dominant discourse in order to change it from within.

Leyla Saz honored other women poets by writing a nazire to a poem by Moralızade Leyla which was itself written as a nazire to a poem by Fitnat Zübeyde. In her poem, Leyla Saz acknowledges both Moralızade Leyla and Fitnat Zübeyde. This chain of poems is evidence of a poetic dialog between women poets across time. I will discuss and compare only the last couplet of each poem. Fitnat Zübeyde’s original poem ends:

Of course Fitnat tells her condition [as] the trouble of the masters are lessons When there is love in heart, poetry shows itself. ${ }^{48}$

Moralızade Leyla wrote the first nazire to it:

I don't have the strength to write a parallel to the late Fitnat

Knowing its fault, the reed reluctantly shows itself. ${ }^{49}$

Leyla Saz writes her nazire to both Fitnat Zübeyde and Moralızade Leyla:

Although I don't have the strength to write parallels to Fitnat and Leyla The dejected broken reef shows itself. ${ }^{50}$

I have already mentioned that Fitnat Zübeyde and Moralızade Leyla are significant women poets in that they were celebrated by male poets; now we also see that they played a prominent role in the history of Ottoman women's writing. It seems that it is Moralizade Leyla who starts the tradition, by acknowledging earlier women poets. She writes poetry not only to commemorate the great Fitnat Zübeyde, but also minor poets like Nesiba Hanım. Many other women poets follow her. For instance, Şeref Hanım (1808-57) was a devout follower of Moralızade Leyla, marking the date of her death with the following poem:

Her highness Leyla Hanım passed away, Şeref surely laments Grief for her injuries the poetic nature and well-proportioned verse

If he were alive, Mecnun would have spoken the date of her death The Kays of death carried Leyla Hanım to the Heaven. ${ }^{51}$

48 "Söyler elbet halini Fıtnat meseldir ehl-i derd / Işk ola bir sinede eş’ar kendin gösterür" (Fıtnat Hanım, “Divan”, İstanbul Üniversitesi, TY 1777, f. 5a).

49 "Fıtnat-1 merhumeyi tanzire yokdur kudretim/ Hame taksirin bilüp naçar kendin gösterür" (Leyla Hanım, Divan-ı Leyla Hanım (Istanbul: Bulak, 1260/1844), p. 10).

${ }^{50}$ Fıtnat ü Leylayı tanzire yok ama kudretim / Hame-i işkeste-i gamhar kendin gösterir (Leyla Saz Hanım, Solmuş Çiçekler, Serhan Alkan İspirli (ed.) (Ankara: Salkımsöğüt, 2008), p. 67).

51 "Hazret-i Leyla Hanım göçdi virür elbet Şeref / Hüzni tab'1 şa'irana nazm-1 mevzuna halel / Sağ olaydı dirdi Mecnun fevtinin tarihini/ 'Adne aldı gitdi Leyla Hanım'ı Kays-1 ecel” (Şeref Hanım, “Divan”, İstanbul Üniversitesi Kütüphanesi, T 2808, f. 144b). 
After lamenting for the loss, Şeref Hanım tells us that Kays/Mecnun, the father of all poets and the ultimate lover in the story of Moralızade Leyla, would honor Moralizade Leyla and register her death date with a poem if he was alive-Kays is his real name, but he was called Mecnun (crazy, mad) because of his love for Leyla. All poets of this tradition are supposed to be madly in love with the beloved, this being one of the virtues of a poet. By mentioning Mecnun and his appreciation for Moralızade Leyla, Şeref Hanım honors both Moralızade Leyla and herself, intimating not only that Moralızade Leyla was a great poet, but also that Şeref Hanım herself displays her mastery of poetry in appreciating Moralızade Leyla's art the way Mecnun would. The ability to evaluate poetry is one of the qualities of a good poet, which returns us to the tradition of nazire writing. By writing nazires, poets not only honor and acknowledge other poets, but show that they can recognize good poetry and write as well as the greats. These lines suggest that women poets, though offering mutual support, are still in competition with each other. Moralızade Leyla was also boasting about herself when she wrote:

Dear Sir, bind Leyla up in the chain of your locks

For she has gone stark raving mad thinking of your lips

How should I not be pleased by the gifts of that court

All the divine gifts in Fitnat were granted me by Mevlana. ${ }^{52}$

In these lines, Moralızade Leyla expresses her pride in being the self-proclaimed successor to Fitnat Zübeyde, saying that God passed all the blessings of Fitnat Zübeyde to her. In other words, Moralızade Leyla sees herself as continuing Fitnat Zübeyde's legacy, not a male poet's, and as passing it on to other women poets. Moralızade Leyla's awareness of her poetic identity, and her embracing of the subcurrent history of women within Ottoman poetry, is surely significant: it is a claim to establish a tradition that has not been acknowledged by the dominant discourse, but, rather, represented as lacking, even though women poets have coexisted with the males throughout history.

By the end of nineteenth century, poets such as Moralızade Leyla and Şeref had claimed the legacy of women's writing within the dominant poetic discourse of Ottoman literature, and created a coexisting entity. Ignoring the tezkires' concerns about women poets' ambiguous education and suspicious morality, they tried to establish themselves as legitimate figures in literary history solely through their own poetic skills. This, surely, explains the sudden

\footnotetext{
52 "Efendim zülfünün zencirine Leyla’yı rabt eyle / Kızıl divane oldı leblerin yad eyleyüp zira / Nice ben olmayam ol dergehin memun-ı ihsanı / Bütün Fıtnat'daki feyzi bana bahş itdi Mevlana" (Leyla Hanım, Divan, p. 3).
} 
increase in the number of women poets in the tezkires from the nineteenth century onwards. By creating their own category, affirming its new qualities, and supporting its members, they tried to establish their own groupings.

Ottoman women's writing progressed over time from being marginal and silent, to being a subcurrent- despite the fact that the way they were represented in the tezkires did not change. As I have tried to showcase in this article, if we look at their poetry from the nineteenth century backwards, it is possible not only to point to specific time periods when their voices were more marginal, silent, or subcurrent, but also to see the end result, which encompasses all of the three categories. Mihri, as a woman poet, was marginal; Moralizade Leyla, however, was marginal, silent, and subcurrent. She was marginal because she was frowned upon based on her marital status; she was silent because she did not write about her reasons for staying single; and she existed within a subcurrent as she was aware of the women poets and entered into poetic dialog with them.

Ottoman women poets from the fifteenth century on established themselves as distinct voices: thus, it would not be wrong to see them as the literary mothers of later women writers who were prominent figures in Turkish women's history, such as Fatma Aliye (1862-1936) or Halide Edip (1884-1964). Fatma Aliye and Halide Edip are among the modern women who addressed issues of women's rights in their own work and in their writing for women's magazines. Having looked at the literary heritage of Ottoman women's writing, it would be anachronistic to define the ideas of equality between genders as Modern and/or Western. On the contrary, they belong to a literary heritage which is five hundred years old.

\section{A step forward: directions for the future}

This article has tried to situate Ottoman women poets as a group that coexisted within the dominant discourse. It has pointed out that the information about them related to us in the tezkires over the centuries may not reflect objective information about them, considering the male bias of the tezkire writers and their specific agendas regarding the strengthening of the dominant voice. Likewise, the study intended to draw attention to methodological issues regarding the study of women poets, suggesting that if we are to reclaim the past and situate women in history alongside men, it is imperative, first, to 'read between the lines' and 'in the margins' of the major histories, and, second, that women's own works should be analyzed in comparison with each other. In this way, it is possible to read women poets as the marginal force 
which sought to challenge the dominant, biased perspective towards women in history. By doing so, it will also be possible not only to discern the outlines of a tradition of women's writing, but also to enhance our understanding of the dominant discourse.

This study asked questions about Ottoman women poets and their presence/absence in the dominant literary tradition, rather than offering answers. To answer the questions that arise, and so to undertake a meaningful study of women poets in the light of the methodological problems I have discussed, will require a close and diligent analysis of their poetry. It will be necessary to study a variety of women poets from a wide range of times, to understand the women's discourse in its opposition to the dominant voice in Ottoman poetry, and to investigate whether they followed similar strategies in interjecting their voices into the dominant system. This question should be addressed by deciphering as many Ottoman women poets as possible, drawing from various genres and different periods. Each women poet should be studied with attention to details such as their diction, use of traditional motifs, poetic techniques, and the use of genre. A step further is always necessary: comparing their work, first, to each other, second, to the male poets and, third, to Persian and Arabic women poets. As we advance through these steps, we will come to know more about Ottoman and Turkish women's literary history.

The research could be further expanded through taking an interdisciplinary approach: we could reformulate the questions raised above, and ask whether Ottoman women raised their voices in the same way in different mediums such as architecture, folk poetry, music, calligraphy, or clothing-expressive media which were more easily available to women. Substantial research has been undertaken in the field of art history and women's contributions to Ottoman architecture..$^{53}$ Is it possible that women's patronage relations in architecture constituted another vehicle for them to raise their voices, just as in poetry?

Moreover, if we switch the focus from composer to the consumer, we will realize that we do not know much about women as consumers of the arts. Although the extant manuscript copies of, for example, Fitnat Zübeyde's Divan suggest a readership, we do not know who exactly the audience is. For instance, did women read women poets more than men did? For two reasons, it is hard to give an answer to this question: first, the manuscript copies do not

53 Bates, Ülkü, "Women as patrons of architecture in Turkey", in Women in the Muslim World, L. Beck and N. Keddie (eds.) (Cambridge MA: Harvard University Press, 1978), pp. 245-60; Necipoğlu, Gülru, Architecture, Ceremonial and Power (Cambridge MA: MIT Press, 1991), and Thys-Şenocak, Ottoman Women Builders. 
always suggest information about the owner(s) and, second, poetry was not only appreciated through reading. It is likely that women's poetry was recited in female gatherings; it would be interesting, though, to know how women's poetry was read and what that meant about the audience of the time.

This kind of research should set out to do two things: analyze the women artists we already know about, and discover new ones who may be hiding in manuscript libraries. Discovering new women artists will be an open-ended inquiry and requires scholarly collaboration. At this point, the documentary evidence is insufficient to answer the questions which have emerged from this study. Although the issue seems to be a 'black hole', with smart methods and strategies, each contribution will illuminate some of the way ahead, and finally it may be possible to reclaim the past and rewrite the history of Ottoman and Turkish women. 